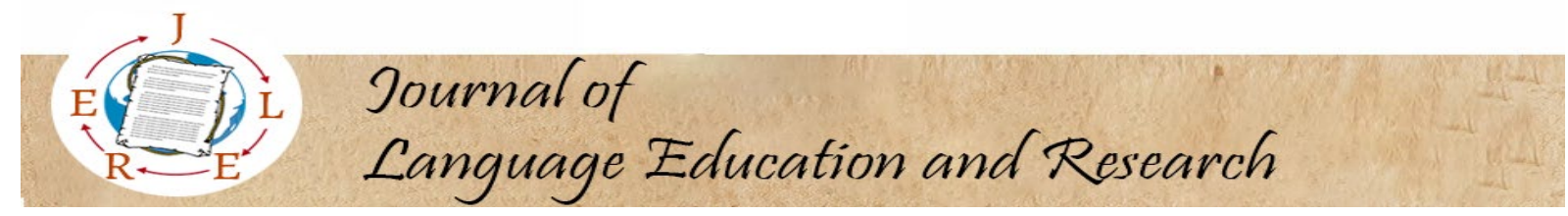

$7(2), 2021$

Journal of Language Education and Research

Research Article

\title{
Users of Children's Sections of Public Libraries: An International Reading Culture Research
}

\author{
Burcu Çıldır * $^{*} \quad$ Emine Akyüz ${ }^{* *} \quad$ Yonca Koçmar Demirci ${ }^{* * *}$
}

\section{ARTICLE INFO}

Received 01.08.2021

Revised form 05.10 .2021

Accepted 12.10.2021

Doi:10.31464/jlere.977345

\section{Keywords:}

Public library

Children's department

Reading culture

\begin{abstract}
This study was designed for learning the patterns of utilization of the children's sections of public libraries and understanding the functions and social elements that library users find in or bring to these sections. The study was designed as a qualitative case study for examining three public libraries (Erzincan, Essen \& Niğde). Data were collected using semi-structured interviews with 72 children and 43 adults in 3 weeks of observation period. Findings for each of three libraries are given under the headings of quality of spaces for children, social climate, and overall picture of activities for children as the "within-case". As to the "across-case" are reached the themes; preschool children, a place like a bookstore, a place like a playground, and reading as a sub-skill for academic success. Considering the functions of libraries in years, it is necessary to involve experts, writers, teachers, and parents in the process as well.

The authors accept the responsibility of this article and all the terms of the journal.
\end{abstract}

This research was conducted with the ethics committee approval of Erzincan Binali Yıldırım University dated 10/09/2021 and numbered 105606.
The authors equally contributed for the article.

The authors declare that there is no conflict of interest. 


\section{Introduction}

It is observed in the literature that studies displaying the efficiency of social elements in developing a reading culture are increased. As matter of fact, reading is described as a social practice embedded in social elements, and how an important role the sociocultural factors play in development of a reading culture is expressed (Lyons, Kotilainen \& Ilkka, 2015; Gee, 2000; Simone, 1999). Such social elements are construed by means of any practices in the child's world in relation to reading, families' relation with reading, and social networks configured for reading (Karadağ, 2013; Sever, 2013; Y1lmaz, 2008; Kamalova \& Koletvinova, 2016). At this point, there is a need of a concept to discuss reading in a larger perspective besides being a cognitive skill.

A concept of reading culture involving cultural and social practices of reading by expressing the social elements thereof is the most comprehensive concept to be utilized. Interaction between various social elements such as public libraries, schools, and families is important in development of a reading culture (Ekici \& Y1lmaz, 2014; Phillips et al., 2017). Nevertheless, it is noted that systematic approaches are very limited for the function of public libraries in the configuration of reading culture when such studies on reading culture are considered, and that the studies on the same subject particularly in Turkey are generally conducted quantitatively. Therefore, the purpose of this study conducted to fulfill the need of developing an in-depth perspective is to present the qualitative research pattern of the role of children's sections of public libraries in the process of acquiring a reading culture in an international perspective.

\section{Literature review}

Public libraries, which increase the social capital with its social interactions and create a third venue in addition to homes and schools, have a powerful impact on creation of a social capital in terms of both corporate and communal context (Varheim, 2017; Karadeniz \& Y1lmaz, 2015). Having provided various shared venues to different parts of the society, fulfilling varying needs thereof, and increasing social interaction and trust, it is not surprising to define public libraries as a force increasing the social capital (Goulding, 2004: 4). In speaking of the social capital, another concept that should be discussed is networks. Falk (2001) mentions that literacy as a tool of communication plays an important role in creation of networks and sustaining such connection when he speaks of literacy in the scope of reading culture. Public libraries as a network do not only assume various functions by means of spaces, social climate, and events they provide, but also nourish the community of users and the social capital of such communities.

The intended uses of public libraries, their users, books, and other products available therein have changed in time in the light of legislations and social developments experienced. Evolutions in education and increased research in children's literature incited children to use newly founded public libraries and school libraries (Lerner, 2007: 254). Features of public libraries were reconfigured for educational purposes suitable for children and special sections for children were created in libraries. Seefeldt and Syre (2004) remark that public libraries were made available to public in Europe after the French Revolution when recounting this historical development. All these endeavors for 
enlightenment of the people resulted in opening new public libraries one after another in early stages just as bookshelves and in later stages, in large scales as of mid-nineteenth century (Seefeldt \& Syre, 2004: 19-20). Although there is a rather old history of book lending services in Turkey, public libraries in the modern perception started in 1920s after establishment of the Republic (Keseroğlu, 1989). Public libraries continued to develop and evolve until present times, and the number of public libraries reached to 7.148 in Germany in 2019 (Saechsische Landesfachstelle für Bibliotheken, 2020), and 1.182 in Turkey (KYGM, 2020).

It is known that public libraries serve to various purposes. Public libraries steer and support the process of acquiring a reading habit by library regulars (Lauristin \& Vihalemm, 2014: 203), and help development of reading as a reading culture, which is a more complex process (Pirlibeylioğlu, 1993: 59-60). Manguel (2006) mentions that public libraries help developing the reading skills of individuals as well as changing their social status. "Public libraries have an important role in the process of structuring the society by establishing bridges between the resources and communal participation" (Scott, 2011). Children's section of public libraries provides various practices and opportunities such as organizing events for children, collections of books and other publications addressing to varying levels, organizing story reading sessions for children and courses for teachers, allocating reading spaces for both children and families, organizing meetings of children and writers, and establishing book clubs, etc. It may be said at this point that the most important function of public libraries to transform reading skills to a new form of intangible human capital (Kotilainen, 2016: 305). To understand better the role of public libraries in the process of acquiring a reading culture, it is necessary to observe the meaning ascribed to reading by library regulars, libraries' functions, and any social characteristics they carry to public libraries.

Current study was designed to learn the patterns of use of children's sections of public libraries and understand the functions and social characteristics that library regulars find or bring to children's sections. In comparison to previous studies focusing on quantitative data or making analyses on local perspectives, we used a qualitative approach and international context (Turkey and Germany). As Kotilainen (2016) mentioned it is important to study library regulars to understand how the quantitative data of the community, which library regulars are members of, are reflected locally. Such a research makes it possible to grasp the facilities and opportunities that individuals of a given community may have in learning to read and transform it into a reading culture. The motivations and reasons for visiting libraries, as voiced by library regulars, help to describe their perspective of reading culture. During the process of the study, the children's sections of three libraries, which have similarities and differences, were examined, and a framework of these three libraries was drawn. The starting point for the researchers is to answer how the children's sections of public libraries as a social network work within the context of reading culture. From this point on, answers to two research questions below were sought:

1. What are the facilities and social elements for children provided by public library children's sections? 
2. What are the general patterns of using public library children's sections and functions thereof attributed by users?

\section{Methodology}

\section{Research design and publication ethics}

The study has adopted the design of a qualitative case study, as the sections allocated to children in public libraries constitute a rich and unique case. Creswell (2016) indicates that in a multiple case study, a subject or issue is selected, and the researcher may choose various programs to study from various places or from several programs in the same place. In the current study on the people using the children's sections of provincial public libraries, multiple cases were included in the scope of the study to sample the selected subject. In this context, the children's sections of the public libraries in Erzincan (Turkey), Niğde (Turkey) and Essen (Germany), where each researcher lives, were included in the scope of the study. The methodology of the case study contains the detailed study of specific, actual, and observable formations that are not separate from society but are part of it. The researcher may arrive at a solution related to the cases studied by mean of collecting and analyzing data from each formation observed (Moorman, 2002: 27). In this process, the authors complied with Research and Publication Ethics and research was conducted with the ethics committee approval of Erzincan Binali Y1ldirım University dated 10/09/2021 and numbered 105606.

\section{Contex}

The sections allocated to children in provincial public libraries, the general outlook of the regulars of these sections, and the meaning they attribute to libraries constituted the subject of the study. Selection of libraries was based on the following criteria: library type (public library), having children's section, accessibility by researcher, cooperation of library staff. Three provincial public libraries in three cities (Erzincan and Niğde in Turkey, and Essen in Germany) were included in the scope of the study. These libraries were selected because the researchers lived in these cities.

As to the cities of study libraries, Essen has a population of around 582.000 (City Population, 2020), whereas Erzincan has 231.517, and Niğde has 352.727 according to the data in 2017 (TÜIK, 2020). All three are the central libraries of the cities where they are located. The children's libraries function as a section of such city libraries. In all three, children's sections are located on the ground floor. Also in Essen Public Library, the children's section has three large spaces. In this section, one of the independent paces is allocated to the children, and the other has resources for the kids aged between zero and six. Between these two independent sections, there is a space containing resources for children aged between 6 and 14 . 


\section{Participants}

In both countries, public libraries are open around the year. Before starting the observation process, the researchers visited the libraries to learn more about the library environments and hold preliminary conversations with librarians. Following the completion of structuring the data collection tools, an implementation plan was drawn up in cooperation with the librarians. The data were collected in three libraries in the period of July to August. The researchers conducted observations and interviews at three libraries for approximately three weeks inside library buildings.

Interviews were carried out with children and adults visiting the libraries during the period when the study was conducted, and observations were performed on how they make use of the space. The library users aged between zero and 18 were considered as child regulars. The ages of the library regulars varied between zero and 68 . The children aged below four were not included in the interviews, but in observations. During the period of the study, activities were organized for children at the public libraries in Erzincan and Essen, but not in Niğde.

Table 1. Participants

\begin{tabular}{l|l|l}
\hline Participants & City & Interview \\
\hline \multirow{3}{*}{ Child Participants } & Erzincan & 32 \\
\cline { 2 - 3 } & Essen & 27 \\
\cline { 2 - 3 } & Niğde & 13 \\
\hline Total & Erzincan & 72 \\
\cline { 2 - 3 } $\begin{array}{l}\text { Adult } \\
\text { Participants }\end{array}$ & Essen & 17 \\
\cline { 2 - 3 } & Niğde & 18 \\
\hline \multicolumn{2}{|l}{ Total } & 43 \\
\hline
\end{tabular}

At three libraries, 72 children and 43 adults were interviewed. The number of interviews per library differed because of the number of users visiting the library during the period of the study.

\section{Data collection and analysis}

The research data were collected through observations, interviews, and research field notes. The data collected from three sources demonstrated not only the case of each library individually, but also made it possible to compare three cases with each other. Creating a robust description providing a sense of how the natural actors in a given setting experience such setting (Schutt, 2006).

\section{Research field notes of researchers}

The researchers paid a visit to respective libraries, introduced themselves to the librarians and briefed them about the study. After getting consent from relevant library management, they spent several days at given library to get a better understanding of the children's section before starting their study. The researchers attended workshops, if any, held at the library to take notes of the information on library regulars. In the stage of data analysis, the data collected from any regular, who attended the workshops, were discussed separately in the section "Activities Conducted at the Library". 
The researchers took field notes to reveal the library uses of library regulars, who took part or not in the interviews. Eight items were determined regarding to the age groups of the regulars of children's sections and their families to have common points in the field notes. Yet, the notes were not restricted only to such items. At the end of each day, the researchers shared these notes with each other, and the points raised during the meetings were added to the notes. The interviews with library staff took the form of asking questions, and occasionally, conversations for clarification of certain matters and served as the sources of the researchers' field notes.

\section{Observation form}

The data related to observations were collected using an Observation Form, developed by the researchers. The Observation Form was structured as having four basic parts: the physical features of library, the quality of library space accessible by children, social climate, and general view of the activities conducted at library. In structuring the Observation Form, a preliminary test was carried out at the library using the form to determine any deficiencies of the form, and necessary corrections were made. In the Observation Form, each part was elaborated by dividing it into sub-items. The total number of items on the form was 17; six items for physical environments, six items for spaces accessible by children, two items for social conditions, and three items for activities. The observations were made at the children's sections of the provincial public libraries.

\section{Interviews}

A semi-structured Interview Form was developed by the researchers to be utilized in the interviews with the regulars of provincial public libraries. Two different Interview Forms were drawn up, as individuals to be interviewed were restricted to children and their parents. After each type of Interview Form was structured, expert opinion was sought regarding to them, and necessary corrections were made before piloting interviews. Following the piloting, the Interview Forms were finalized.

All participants of the study were natural library regulars. Which regulars would be taken within the scope of the study was determined at the days when the researchers were at given libraries, and no prior planning was made. The mother tongue of all participants from Turkey is Turkish. As to the regulars in Germany, some spoke German while others were bilingual (Turkish and German). The interviews with such participants were conducted in Turkish and German with the help of another bilingual researcher, who helped the study. The number of the participants interviewed is given in Table 1.

The adult and child participants were first inquired about their gender, age, educational background, and profession. Then, the semi-structured interviews were held when they were asked about frequency of using library, people accompanying them, purpose of visiting a library, manner of making use of a library, how a library setting is perceived, and communications with librarians. The regulars visiting the children's sections were briefed about the study and asked if they would agree to participate therein. The interviews were held with those agreeing to participate in a suitable place within 
libraries or at the desks available in children's sections. The interviews were conducted simultaneously with observations. Each interview with an adult or a child took approximately 15-20 minutes while being recorded using a voice recorder.

\section{Procedure}

In the present study designed as a multiple-case study, multiple cases were included in the study framework for sampling selected subjects. First, the themes within each case were analyzed in detail using the method of "within-case analysis". Then, a comparative thematic analysis was performed among the cases using the method of "across-case analysis" to interpret the case. When multiple cases were selected, first, the themes within the cases were analyzed using the method of "within-case" analysis, and then, a comparative thematic analysis is performed among the cases using the method of "across-case analysis" to interpret the case (Creswell, 2016: 101). In line with these steps, in the present study, each case was defined within itself and then, the themes that emerged following the method of "across-case" analysis were presented.

The interviews held with library regulars at three different libraries using a voice recorder were transcribed. The observation and field notes taken by the researchers were also typed. In the present study, firstly, inductive analysis was performed and all the data from observations and interviews were coded. Inductive analysis consists of discovery of patterns, themes, and categories within the data (Patton, 2014: 453). Each researcher coded her own interviews, observations, and field notes. In the second phase, all the coding was combined, and all three researchers collectively reviewed the codes and created the categories. During the creation of categories, the overlapping data were reviewed and the data falling outside the categories were removed, and the patterns were obtained. The "within-case" analysis was performed under the headings of physical features (location, library space, shelving, and collection) of libraries, quality of spaces available to children, social climate, and general view of activities for children.

\section{Results}

The findings consist of two parts. These parts were created based on two research questions formulated within the context of the aim of study. The first part pursued an answer the question "What are the facilities provided by public libraries for children?" The within-case status of each library was demonstrated. The second part tried to find the answer to the question "What is the general outlook of the regulars making use of such facilities and the meaning they attribute to public libraries?" The themes emerged when the cases were compared were listed.

\section{Within-case findings}

\section{Reading facilities in the children's section of Essen Public Library}

Quality of spaces for children: The sitting areas are arranged based on age groups; each area has desks and chairs with proper sizes for targeted age groups. In addition, there are three armchairs in front of windows and four desks with chairs for adults in the sections for the 0-6 age group. There is a wooden sitting area with stairs covered many 
colorful cushions thereon, normally used for story reading activities. It was observed that families preferred to use this area for reading books to their children outside the activity hours. Children use this area and an area covered with the Twister game figure for playing games. The noise levels in the sections decline as the age groups increase. There are three computers, one in each department, used for searching the catalog. In addition, there is a round table with a tag "Child and Computer" with three computers thereon and nine stools around it. During the observation period, children used these computers solely for playing games. The books and materials in the children section are classified according to age groups. Additionally, there is a section for the bilingual books, including Turkish-German, Arabic-German, Russian-German, and Chinese-German ones especially for preschool era in separate boxes. The number of Turkish-German books in this section was reported by the library manager as 295 .

Social climate: In the children's section, there are lavatories and a baby changing room equipped with all the needs considered. In addition, there is a cafeteria called "Literaturcafe" inside the library servicing to regulars, including breakfast during the working hours (08.00-17.00) with its indoor and outdoor areas. The entire library and the children's section are designed for accessibility by wheelchairs. The library with high access also has an elevator. The children's section has audiobooks for the visually impaired people and such areas suitable for listening to such books.

General view of activities for children: The activities that adults can monitor are the activities slated for the age group "4 years and above" and "7 and above". The librarians cite the individualities of children and lack of sufficient space for the participation of adults.

The facilities provided by the children's section of Essen Public Library, as a whole turn, the library into a social living space for its regulars. The library provides children and adults with various opportunities for social interaction as children can read books, play games, or attend workshops, etc. with their parents or peers. The approach adopted by the children's section of Essen Public Library expresses that the library authorities no longer regard reading restricted only to printed books or borrowing books but turn it into a process through which children can improve their life skills. Thanks to such facilities, the library could be embedded culturally in the daily lives of children and parents. This is believed to promote library regulars in terms of reading culture.

\section{Reading culture facilities in the children's department of Erzincan Public Library}

Quality of spaces for children: The children section is located on the library's ground floor. The section is clearly marked with a label reading "Children's Section". The floor thereof is covered entirely with tiles. The room is sufficiently heated, but not equipped with an air conditioning system. The room appears poorly illuminated, especially at the corner away from windows. The corner in question has some tables and shelves. The tables and chairs in the children's section are colorfully designed suitable for sitting by children up to 5-years old; nevertheless, there are no sitting areas designed for younger or older children. In addition, there are no areas for different activities; rather, the children's section is designed as a reading hall, which can also be used by children up to 18 years old. 
The books are not lent to non-subscribers, although they can make use of study halls and read books in the children's section. There are approximately 14,000 books at the children section and there are not any materials other than books.

Social climate: There is a special hall at the library designed solely for visually impaired individuals; therein, there are four computers available for them. The computers are always on and in working condition, but the staff noted that there is not visually impaired regular of the library. The library does not offer transportation services for people with disabilities; however, the entrance of the library is designed to allow easy access by such people. The book lending services are located on the ground floor, but there are apparent difficulties for people with physical disabilities to access to the upper floors to make use of the study halls. This is because of lacking an elevator facility in the building. Furthermore, there are no social facilities such as cafeteria, change room, etc. in the building.

General view of activities for children: During the observation period, a 3-week event for the summer period was organized at the library. The activities to be included in the event were determined by the library staff in cooperation with the field experts. There was an activity every day except Sundays. The activities, such as Story Time, Healthy Lifestyle Seminar, Music Recital, Drama, Self-Protection Seminar, and Art Workshop were open to all participants. Thanks to personal efforts of the library director, participation by the groups of summer school and rehabilitation center students upon prior arrangement was high, but voluntary participations were limited.

The children's section of Erzincan Public Library has only bookshelves and tables. Various workshops of arts are also organized for children in this area. However, any children and adults, who were reported as voluntary participants to any activity, represent the individuals, who became aware of and decided to attend such activities for a while after coming to the library to borrow books. None of any voluntary participants came to the library just for attending the events. The fact that the children's section has been designed only for facilitating the act of reading printed materials is proof of the traditional perspective regarding the reading culture. This approach isolates the act of reading from its social setting and restricts the library's function for mediating the development of reading.

\section{Reading culture facilities in the children's section of Niğde Public Library}

Quality of spaces for children: In the children's section, there are two tables with three chairs and no playground around. Although the tables and chairs are designed specifically for children, they are not comfortable for using by children in terms of height, etc. There is no area allocated to preschoolers. There is no quiet room only for children. Children try to be as quiet as possible in the book lending section.

Social climate: There are lavatories and a canteen on the lower floor within the same building. There is an elevator for disabled people to access to the library, but no special room for disabled regulars in the children's section.

General view of activities for children: No activity was organized for children during the study period. The library staff noted that a story reading activity was organized for preschool children only once to promote the library to children. 
The children's section of Niğde Public Library consists of several bookshelves and tables in a small room. The book lending service and the reading section are in the same space, effectively restricting the area of movement of readers therein. In addition, there are only few seats in the children's section making it impossible to organize any event therein. Allocation of such a limited space to the library restricts its function solely to book lending and makes it hard for readers to utilize any other function of reading at the library. These restrictions related to the library spaces allocated for utilization by readers create problems in a way the library can promote the reading culture process of readers.

\section{Across-case themes}

\section{Social characteristics of readers}

In Niğde, regulars of the library are generally the primary and secondary school children aged 6 to 14. Primary school students come to the library generally with their mothers, whereas secondary school students alone or with friends. Likewise, the library regulars in Erzincan are mainly the children over six years old. Some secondary school students come to the library alone while most primary school students are accompanied by their parents whereas some are accompanied by their siblings attending secondary or high schools. It was observed that in Essen, the children aged below 12 in average come to the library with their parents, although some users aged 12 to 19 years old visit the library alone, or with their friends and sit as a group. The library regulars in Niğde and Erzincan did not demand any social interaction in library environments. On the other hand, in Essen, individuals are incorporated into the library setting with a broader social circle, and their experiences in terms of the reading culture are more diversified as a result.

Through the gender profile, virtually all the adults, who visited the children's sections of the libraries in Niğde and Erzincan, were mothers, whereas some fathers visited the library's children's sections very occasionally. The mothers came alone or with their children to borrow books only for their children, not for themselves. The ages of the mothers using the library varied from 30 to 45 . Upon an inquiry whether she came to the children's section only, a mother answered "Yes, for the time being. I currently focused on my children; therefore, we visit the dedicated sections. I cannot spare much time for myself; therefore, we use the children's sections only" (ER6/F/33). ${ }^{l}$ Thus, the mothers in this location stated in general that they borrowed books only for their children because they did not have time for themselves. In Essen, parents and grandparents accompanied their children or grandchildren. There was no significant difference in terms of gender or any age group. There were even grandparents coming alone to use the children's section: "I come to this department to select books for my baby grandchild. I borrow books and take them to him/her. Sometimes, I bring my grandchild as well. My workplace is around neighborhood. I will borrow a book and go back. There is a good selection of children's books here" (ES8/M/48). In Niğde and Erzincan, task of promoting reading to children is assumed solely by mothers and utilize libraries in the process. Although this task is performed solely by mothers in families, it undermines the process by which children

\footnotetext{
${ }^{1}$ City, number of participants, gender, and age were specified in the codes, respectively.
} 
could establish bonds with libraries and weakens their reading-related practices which they could internalize by transferring from library to their daily lives. In Essen, social environment, which is a natural part of daily life, is transferred to the library environment. This, in turn, paves the ways for children to transfer reading practices to their family and other social settings.

\section{Ghost visitors, preschool children}

In the public libraries of Niğde and Erzincan, it was observed that parents generally did not borrow books for their preschool children. When they borrowed, they did it only during the extra time left over after selecting books for their schoolchildren when they accompanied their primary/secondary schoolchildren. One of the mothers interviewed made the following comment: "My daughter selects her books on her own. She is nine years old. The younger one does not know how to read. She is only five years old" (NI4/F/34). In Niğde, there was no library regular coming to the library with his/her preschool child solely to borrow books for the child. In Erzincan, it was observed that only some mothers came to the library with their preschool children after the teachers of the children attending to a preschool facility promoted the use of the library.

Children can become subscribers of the children's sections of the public libraries in Niğde and Erzincan only after they start to attend a primary school. Preschool children can borrow books only through their parents or their adult relatives as a workaround. Yet, this practice gives the impression to parents that a preschool child is not expected to read books. However, small children, who are accompanied by their parents and elder siblings, select, and try to read books or make sense of them by just looking at the pictures in them. "Only one of my children can use the library. The other one cannot use it because s/he cannot read and write but looks around and observes us when we visit the library. This applies to the youngest one as well" (Nİ1/F/38).

Even though the very foundations of reading skills of children are laid during the preschool era, it was observed that preschool children were unable to make sufficient use of the libraries in Niğde and Erzincan. Although some books designed for preschool children were available in the libraries, such approach of families and the library led to the reduction of reading practice to the act of reading through printed letters.

\section{A place looking like a bookstore}

In Essen Public Library, most of the participants described themselves as library regulars. They noted that they visit the library at least once a week. When inquired about the frequency with which she used the library, a girl said, "In general, I come to the library in order to do my homework; therefore, I come here either every day or at least every other day" (ES3/F/11).

In Niğde and Erzincan, on the other hand, the readers indicated that they visit the library once in every 15 days or once a month: "We borrow three books and come back in 10-15 days. We leave the library as soon as we borrow the books. We stay for 5-10 minutes in the library" (NI/F/34); similar responses were common. Likewise, a mother using the library in Erzincan described her visiting frequency as follows: "Once in 15 days 
and it changes every time. If the book is read already, we come back once a week. It is because we live in a far distant location..." (ER/F/35). The reason for citing the frequency of visits to the library as once in every 15 days is apparently the maximum duration of 15 days for borrowing a book. When a mother was inquired about her last visit to the library, she was puzzled with the question: "15 days ago, as usual. This is because we have 15 days for returning the books borrowed" (ER11/F/40). Some participants rarely took their children along to the library so that they might be introduced to the books. Yet, the time spent at the library did not exceed half an hour. "We come to the library so that my daughter, who graduated to the second grade, can acquire the habit of reading and observe the library climate, and feel and touch various books. When we come here, we read a few books and borrow our quota of three books for returning them in two weeks. We spend at least half an hour at the library during each visit" (Nİ3/F/33).

It is evident that the users of the public libraries in Niğde and Erzincan tend to see the library as a place where they can exchange books. The duration for borrowing a book is 15 days; readers may come for borrowing books again when the time is due and visit even before then. Yet, the reason for an earlier visit is the finishing of reading a borrowed book. Upon finishing the reading of any current book, the reader visits the library for another one. The relationship of readers with the library fail to evolve into a social habit as this relationship remains restricted to borrowing books only.

\section{A place like a playground}

Public libraries are no longer just a building from where books are borrowed but became such venues influencing the relation of child with books in different ways (events, reading hours, meeting of literates, parents' seminaries, etc.). However, functions of libraries change in line with sociocultural changes. While families in Turkey go to libraries mostly for borrowing books, families in Germany consider libraries as a social environment and spend time in libraries.

The regulars of Essen Public Library had diverse objectives in using the library. Some children indicated that they went to the library to play games, saying, "We generally come to the library to play card games" (ES16/M/7). A user considering the library as an entertaining venue explained her reason for coming to the library as follows: "I come from another city. This library has many games. The library in the city where I live has a rich collection just like this one, but there are more games here. So, when I visit my relatives in this city, I come to this library with my cousins to play games" (ES20/F/9).

Some library users visited Essen Public Library for renting movies, ensuring the participation of their children in the activities, borrowing books and doing homeworks: "We come to the library to play games and chat with my friends. Therefore, we come to the children's section in order not to disturb the others studying. This time, we are just two of us, but most of the time, we come as a large group. So, we become noisy to some extent" (ES/F/14). "The kids would be with me in two visits out of three; they make better use of the library than me. We primarily come for borrowing books and CDs, and sometimes, renting games and movies. When I come here alone, I generally borrow resources for improving my German" (ES6/M/38). 
It is observed that readers in Niğde and Erzincan have no expectations from libraries as a social network. In the period of observations in Niğde Public Library, there was no event organized for ensuring such social network. However, although there are free events in Erzincan Public Library such as movies for public access, children's theatres, conferences, etc., library users do not prefer to attend to such events. When asked of their expectations from the library, users mostly expressed their recommendations and requests for physical elements of the library "It could have been a bit larger, working areas could be more spacious and environment could be more lighted. The environment could have more picture that can attract children's attention" (ER1/F/33).

This outlook in Essen diversifies not only the habits of regulars utilizing public libraries, but also relationships thereof with the act of reading. As readers go beyond the simple act of borrowing and reading printed books and participate in various activities in an environment characterized with books, public libraries become part of their social living spheres. It is obvious that having libraries becoming a social network is not related just to organize some events in libraries. Having no expectation by the users in Niğde and Erzincan for libraries being such a social network may be associated with that fact that they have no such necessity in their lives. The meaning of libraries attributed by librarygoers is important in constructing such social networks they bring in and received from libraries.

\section{Reading as a sub-skill for academic success}

It was observed that teachers played an important role in the social circle of children in relation to public libraries. Almost all secondary schoolchildren visiting Erzincan Public Library alone stated that their teachers promoted the use of library. Some of them indicated that they were library regulars since their primary school years. The children were similarly motivated for visiting the library in Niğde as well. In Essen, the children were guided by their parents and teachers for using the library; however, the former acquired the habit of using the library at early ages.

Many users of two public libraries in Turkey stated that they borrowed mainly novels and stories. In the search of the underlying reason thereof, we came across to the significance that parents and schools attached to academic achievement. A user commented as follows: "We buy the books needed our courses whereas borrow books from library for reading" (NI/F/37). In this context, it was observed that parents considered reading books as a sub-skill promoting academic achievement and perceived libraries as the places facilitating this. A father, who brought his child to the library in Erzincan, said about the libraries: "I must note that I have been using the libraries since my childhood, my secondary school years. I have passed all my exams since I became a library regular. I have become successful in all exams I took. I owe it to reading books; I still read books as you see. But my kid is not good at reading books" (ER9/M/46). It is evident that the father prioritizes academic success by taking his child along to the library so that s/he can be successful at exams.

Although the influence of teachers regarding how children are introduced to libraries was visible in all three cities, the tendency to construe reading in connection with 
academic achievement in Niğde and Erzincan affects the bond that children establish with books. These observations imply that the act of reading is priced based on its contribution to academic achievement.

\section{Discussion}

In this study, the qualitative case study method was utilized for comparative examination of the children's sections of three public libraries in two countries with separate reading and library data. The different lenses on the reading culture they accommodate as well as the differences and similarities in the reader profiles and facilities of these three libraries were presented through various salient motifs. It was found that two countries differed in terms of both library users and facilities provided by the libraries, whereas the public libraries in Niğde and Erzincan, had similar motifs.

It is known that in communities with high levels of reading culture, the numbers and functions of libraries are broader (Ekici \& Y1lmaz, 2014; Lauristin \& Vihalemm, 2014). It was found that the readers in three cities spent their time in children's sections of the public libraries through different activities. In consideration of how these functions affect the library regulars, it was observed that the users of the children's section of Essen Public Library had more diverse objectives in using the library. The reasons for visiting a public library can be very diverse; desire to search for a particular kind of literature, browse the latest magazines, check on the new arrivals at the library, etc. (Lepik, 2013). On the other hand, it can be maintained that parents and children identified the public libraries in Niğde and Erzincan primarily as a facility for borrowing and returning books. At this point, it is very likely that the physical facilities of two libraries in Niğde and Erzincan played a role in this process. It is very hard for public libraries to attract visitors when they are designed as a social environment. Even if parents focus on the academic achievement aspect of reading, Sin (2009) argues that the academic use of school libraries is stronger while use of public libraries may include a more social component. Referring to libraries as treasures, Pihl, van der Kooij and Carlsten (2017) assert that well equipped libraries should offer various facilities such as books, music, newspapers, Internet access, and games, and only such sophisticated and diverse resources may attract children with different skills to the library. Libraries essentially fulfill the deficiency of bond and connection between readers and knowledge. Accordingly, varying needs of communities also transforms and diversifies the functions of libraries. "Libraries, nowadays becoming such centers to support both formal and informal communications between individuals, contribute to socialization of individual, and hence, to the social capital" (Karadeniz \& Y1lmaz, 2015).

Preschoolers emerged as an invisible social group in the libraries both in field and in practice in Niğde and Erzincan. The literacy experiences in the preschool period have a direct impact on the development of reading culture in later periods (Scarborough, Dobrich \& Hager, 1991). It is crucial to increase the number of activities geared toward preschool children in libraries to ensure the development of reading culture in society. At the same time, in this period, children need support of an adult mostly for development of literacy abilities. It is possible to say that involving libraries and book in the relation of parents and 
children may strengthen such relations Such activities may be those requiring parents and children visiting libraries together. "Artistic workshops, such as language, career, technology courses, painting, and music, positively affect the levels of social confidence of participants as result of acculturation. Consequently, such a small network of relations of individuals created in libraries have an impact on the social capital at communal scale" (Karadeniz \& Y1lmaz, 2015: 193).

The motivations of families in Turkey for utilization of children's sections of libraries seem to be related to their knowledge and experiences regarding libraries as well as designing library spaces and any activities organized therein. Since libraries are an unfamiliar public venue for families, families may not feel safe therein for being together with their children (Lingwood, Billington \& Rowland, 2020).

\section{Suggestions}

When the children's sections of public libraries are reorganized to address the emerging needs, the readers' perceptions of libraries as "book borrowing places", particularly for Turkey, may be eliminated. Preschool children should be allowed becoming official subscribers of libraries to enhance the allure of libraries for preschool children. An environment may be created in which experts of children's literature, experts of information and document management, teachers, pre-service teachers, librarians, children, and parents may work together.

Further research could focus on gender, social class, and explore relations between cultural resources and libraries in other context (e.g., different countries or different type of libraries). Moreover, qualitative studies on library users and function of libraries could further elaborate the association between social and cultural capital and reading culture.

\section{Conclusion}

Libraries are crucial in gaining various skills for reading in the process of acquiring the reading culture with the social practice they provide. Public libraries are no longer just a building from where books are borrowed but became such venues influencing the relation of child with books in different ways (events, reading hours, meeting of literates, seminaries for parents, etc.). It was found that there were many different variables involved in the process by which libraries mediate the reading culture; such variables can be explained both as the socio-cultural elements of libraries and as social practices introduced by readers to library settings. The way in which a library space is structured, the social climate of libraries, or the nature of events organized shape the facilities of the reading culture within a library setting. As result, the facilities provided by libraries as well as the profiles of their regulars help to understand how a reading culture in a library setting is reflected on the society at a micro level.

While families in Niğde and Erzincan go to libraries mostly for borrowing books, families in Essen consider libraries as a social environment and spend time in libraries. Such differences in utilization of libraries seem to be related to users' sociocultural characteristics. The fact of families in Niğde and Erzincan borrowing books from libraries mostly for their school-going children, not preschool children, indicates that families 
associate reading books with literacy. Facilities provided in the children's sections of libraries and the looks of users of these sections demonstrate how the reading culture is reverberated to the society at micro levels.

For involving the children's sections of public libraries in the daily lives of individuals, it is essential to arrange those venues in such a way to fulfill interests, pleasures, and needs of children. It is advisable to consult and make certain arrangements together with librarians, professionals, families, and educators regarding such social practices to activate the social network function of libraries by means of both national and international regulations at practical levels.

\section{References}

City Population (2020). City population-Essen. https://www.citypopulation.de/en/germany/nordrheinwestfalen/nordrhein_westfalen/05113 000 essen/

Creswell, J. W. (2016). Nitel araştırma yöntemleri: Beş yaklaşıma göre nitel araştırma ve araştırma deseni [Qualitative inquiry \& research design: Choosing among five approaches]. Ankara: Siyasal Kitabevi.

Ekici, S. \& Yılmaz, B. (2014). Ankara'daki anaokullarının okuma alışkanlığına hazırlık yeterlilikleri açısından değerlendirilmesi [Evaluation of the Reading Habit Readiness Adequacy of Kindergartens in Ankara]. Türk Kütüphaneciliği, 28(4), 547-582.

Erzincan İl Halk Kütüphanesi (2020). Tarihçe [History]. http://erzincan.kutuphane.gov.tr/TR61949/tarihce.html

Falk, I. (2001). Literacy by Design, not by default: social capital's role in literacy learning, Journal of Research in Reading. 24(3), 313-323.

https://doi.org/10.1111/1467-9817.00152

Gee, J. P. (2000). Discourse and sociocultural studies in reading. In M.L. Kamil, P.B. Mosenthal, P.D. Pearson, \& R. Barr (Eds.), Handbook of reading research (Vol. III, pp. 195-207). Mahwah, NJ: Erlbaum.

Goulding, A. (2004). Library and Social Capital- Editorial. Journal of Librarianship and Information Science, 36(1), 3-6.

https://doi.org/10.1177/0961000604042965

Kamalova, L. A. \& Koletvinova, N. D. (2016). The problem of reading and reading culture improvement of students-bachelors of elementary education in Modern High Institution. International Journal of Environmental and Science Education, 11(4), 473-484. https://doi.org/10.12973/ijese.2016.318a

Karadağ, Ö. (2013). Okuma kültürüne katkıları bakımından Türkçe ders kitaplarının resimlemeleri (illüstrasyonları) [Illustration in Turkish coursebooks with regard to its contribution to reading culture]. Eğitimde Kuram ve Uygulama, 9(2), 84-93.

Karadeniz, Ş. \& Yılmaz, B. (2015). Sosyal sermaye bağlamında kütüphane kurumu [The Library in the context of social capital], Bilgi Dünyast, 16(2), 180-203.

https://doi.org/10.15612/BD.2015.487

Keseroğlu, H. S. (1989). Halk kütüphanesi politikası ve Türkiye Cumhuriyeti'nde durum [Policy of public library and situation in Turkish Republic]. İstanbul: Edebiyat Fakültesi Basımevi. 
Kotilainen, S. (2016). Literacy skills as local intangible capital, the history of a rural lending library c. 1860-1920. Helsinki: Finnish Literature Society SKS.

KYGM (2020). 2015-2019 yllları halk kütüphaneleri genel istatistikleri [2015-2019 General statistics of public libraries]. https://kygm.ktb.gov.tr/TR-204967/2015-2019-yillari-halkkutuphaneleri-genel-istatistikle-.html

Lauristin, M. \& Vihalemm, P. (2014). Reading in changing society. Tartu: University of Tartu Press.

Lepik, K. (2013). Governmentality and cultural participation in Estonian public knowledge institutions. Doctoral Dissertation. Tartu: University of Tartu Press.

Lerner, F. (2007). Kütüphanelerin hikayesi [The history of libraries]. (Trans. D. Çenkçiler). İstanbul: Bileşim Yayıncılık.

Lingwood, J., Billington, J. \& Rowland, C. (2020). Evaluating the effectiveness of a 'realworld' shared reading intervention for preschool children and their families: A randomised controlled trial. Journal of Research in Reading, 43(3), 249-271.

https://doi.org/10.1111/1467-9817.12301

Lyons, M., Kotilainen, S. \& Ilkka, M. (2015). The functions and purpose of vernacular literacy: An introduction. Journal of Social History (Special Issue: The Functions and Purpose of Vernacular Literacy), 49(2), 283-286.

https://doi.org/10.1093/jsh/shv034

Manguel, A. (2006). The library at night. New Haven \& London: Yale University Press.

Moorman J. A. (2002). Combined school/public libraries in the United States: Three comparative case studies. Doctoral Dissertation. University of Illinois at Urbana-Champaign the Graduate College.

Niğde İl Halk Kütüphanesi (2020). Tarihçemiz [History]. http://nigde.kutuphane.gov.tr/TR103048/tarihcemiz.html

Olasehinde, M. O., Akanmode, O. A., Alaiyemola, A. T. \& Babatunde, O. T. (2015). Promoting the reading culture towards human capital and global development. English Language Teaching, 8(6), 194-200. http://dx.doi.org/10.5539/elt.v8n6p194

Patton, M. Q. (2014). Qualitative research \& evaluation methods: Integrating theory and practice. California: Sage Publications.

Phillips, A., Crocker, R., Leege, R., Turner, J. \& Ebo, E. (2017). Building a reading culture through partnerships. IFLA. 1-10.

http://library.ifla.org/id/eprint/1747

Pihl, J., Van Der Kooij, K. S. \& Carlsten, T. C. (Eds.). (2017). Teacher and librarian partnerships in literacy education in the 21st century. Rotterdam: Sense Publishers.

Pirlibeylioğlu, M. (1993). Okuma alışkanlığının geliştirilmesinde kütüphanelerin rolü ve önemi [The role and importance of the libraries in development of reading habit]. In 1. Halk Kütüphaneciliği Sempozyumu Bildiriler (Symposium on Public Libraries). Ankara: Kütüphaneler Genel Müdürlüğü. 59-61.

Saechsische Landesfachstelle für Bibliotheken (2020). DBS-Gesamtauswertungen für 2019 veröffentlicht (Overall evaluations for 2019 published). https://www.lds.sachsen.de/bibliothek/?ID=16632\&art_param=957\#

Scarborough, H. S., Dobrich, W. \& Hager, M. (1991). Preschool literacy experience and later reading achievement, Journal of Learning Disabilities, 24(8), 508-511. 
https://doi.org/10.1177/002221949102400811

Schutt, R. K. (2006). Investigating the social world: the process and practice of research. North America: SAGE Publications.

Scott, R. (2011). The Role of Public Libraries in Community Building, Public Library Quarterly, 30(3), 191-227.

https://doi.org/10.1080/01616846.2011.599283

Seefeldt, J. \& Syre, L. (2004). Geçmişe ve geleceğe açılan kapı Almanya'da kütüphaneler [The door opens past and future libraries in Germany]. (Trans. M. Arun). Hildesheim: Georg Olms Verlag.

Sever, S. (2013). Çocuk edebiyatı ve okuma kültürü [Children's literature and reading culture]. İzmir: Tudem Yayıncilık.

Simone, K. (1999). Public libraries as partners in youth development. New York: DeWitt Wallace-Reader's Digest Fund.

Sin, S.-C. J. (2009). Structural and individual influences on information behaviour. A national study of adolescents' use of public libraries. Doctoral Dissertation. University of Wisconsin- Madison.

Stadtbibliothek Essen (2020). Informationszentrum stadtbibliothek (Information about the library). https://www.stadtbibliothek-essen.de/ueber_uns/ueber_uns.de.html

TÜİK (2020). Ill ve cinsiyete göre il/ilçe merkezi, belde/köy nüfusu ve nüfus yoğunluğu (Population of province/ district center, town/ village by city and gender), 2017, https://data.tuik.gov.tr/tr/display-bulletin/?bulletin=adrese-dayali-nufus-kayit-sistemisonuclari-2017-27587\#

Varheim, A. (2017). Public libraries, community resilience, and social capital, Proceedings of the Ninth International Conference on Conceptions of Library and Information Science, Uppsala, Sweden, June 27-29.

Y1lmaz, B. (2001). Avrupa Birliği (AB) ülkeleri ve Türkiye'de halk kütüphaneleri: Niceliksel bir karşılaştırma [Public libraries in the European Union (EU) countries and Turkey: a qualitative comparison], Türk Kütüphaneciliği, 15(4), 378-398.

Yılmaz, B. (2008). Çocuklarda okuma kültürünü geliştirmede ebeveyn ve öğretmenin rolü [Role of parents and teachers in developing reading culture of children]. In Çocuk ve Okuma Kültürü Sempozyumu (Symposium on Child and Reading Culture). Eğitim-Sen Yayınları, 133-140. 